\title{
Analysis of Coping Behavior of Parents Who Have Children with Special Needs (Autism) in Public Special School 1 Kendari
}

\author{
Rani Muhammadi ${ }^{1}$, Sudirman Nasir ${ }^{1}$, Yahya Thamrin ${ }^{2}$, Ridwan M. Thaha ${ }^{1}$, Arifin Seweng ${ }^{3}$, \\ Citrakesumasari $^{4}$ \\ ${ }^{1}$ Department of Health Promotion, Faculty of Public Health, Hasanuddin University, Indonesia \\ ${ }^{2}$ Dapartment of Occupation Health and Safety, Faculty of Public Health, Hasanuddin University, \\ Indonesia \\ ${ }^{3}$ Department of Reproduction Health, Hasanuddin University, Indonesia \\ ${ }^{4}$ Department of Nutrition, Faculty of Public Health, Hasanuddin University, Indonesia
}

\begin{abstract}
Autism Spectrum Disorder (ASD) is a condition characterized by several levels of social behavior, communication and language that is disturbed by various interests and narrow activities that are unique to the individual and carried out repeatedly. Parents need coping to understand the condition of children with special needs. This study aims to analyze coping behavior in parents who have children with special needs (autism). This research is a qualitative research with a case study approach. The data were obtained by means of in-depth interviews and observations on 14 informants consisting of families, parents and health workers as well as teachers and principals Public Special School 1 Kendari. Content analysis is used to identify topics or categories in data. The results showed that coping behaviors were used to overcome feelings, namely worship, crying, patience, keeping busy and entertaining themselves. Coping behavior to overcome the condition of children with special needs (autism) in the form of following therapy, dietary food, teaching children at home, alternative medicine and taking medication. To support coping efforts, parents get support from family, friends, school principals, teachers and therapists. It is recommended that Special School 1 Kendari be able to increase the understanding and knowledge of parents about autism by holding training for parents who have children with autism, how to handle children with autism so that parents gain understanding and help parents' difficulties in working with children with autism.
\end{abstract}

Keywords: Autism, Child Special Need, Parents, Coping Behavior

Received: October 23, 2020

Revised: November 9, 2020

Accepted: November 18, 2020

\section{Introduction}

Children with special needs according to the Ministry of Women's Empowerment and Child Protection of the Republic of Indonesia (2013) is a child who experiences limitations or extraordinaryness, whether physical, intellectual, mental, social, or emotional, which have a significant influence in the process of growth or development compared to other children of the same age. According to the World Health Organization (WHO) (2019), Autism Spectrum Disorder (ASD) is a condition characterized by several levels of disturbed social behavior, communication and language, with various interests and narrow activities that are unique to the individual and carried out repeatedly.

Symptoms of autism appear before the age of 3 years regardless of socio-economic strata, parental education level, race, ethnicity, or religion. Children with autism from birth are called classic autism, while children with autism disorders that appear after the age of 1.5 to 2 
years are called regression autism (Ekaningtyas, 2019). Individuals with autism often show other conditions that occur, including anxiety and depression Rieffa et al (2014), having difficulty managing emotions (Berkovits et al., 2017; Samson et al., 2015). As well as externalizing behavior, such as aggression and hyperactivity (Ashburner et al., 2008).

Data from the World Health Organization (WHO) In 2016, 35 million children with autism were recorded worldwide. Data Center for Disease Control and Prevention (CDC) (2020) in the United States, The number of people with autism spectrum disorders has increased by $2.1 \%$ compared to 2014. In Indonesia, there has been no specific research to find the incidence of autism, only from the observations of several experts, it is found that there is an increasing trend in cases being handled (Soetjiningsih, 2014). In 2015 it is estimated that one per 250 children have autism disorders and it is estimated that there are approximately 12,800 children with autism (Judarwanto, 2015).

Based on prevalence data, it shows that autism disorder continues to increase and the problem of autism disorder is more complex than other developmental disorders causing increased inner conflict between parents in dealing with children with autism disorders (Daulay, 2016). There is a gap between the expectations of every parent who wants a child to be proud of and the fact that their child has developmental disorders in the form of autism, is a trigger for conflict or mental pressure on parents (Rahayu et al., 2019).

Parents generate various emotional reactions when they first find out that their child has an autism disorder such as shock, denial, feeling distrustful, sad, feeling too protective or anxious, feelings of rejecting circumstances, feelings of inadequacy and shame, feelings of anger, feelings of guilt and sin, taking steps step by step, and the struggle has not ended (Safaria, 2005).

Parents need to understand and be aware of these emotions in order to have the ability to manage them effectively. Emotional management skills begin with realizing the emergence of these emotions, then trying to understand what they are and accept these emotions as part of life. Only then will parents be able to control emotional reactions so that they are not easily trapped in an environment of emotional turmoil. If parents are caught in a circle of emotional power, So many negative impacts are felt by parents, both physically and psychologically (Safaria, 2005).

Symptoms of depression, anxiety, worry, feelings of hopelessness or stress are the effects that parents feel. Many parents of children with autism experience high levels of stress and / or depression (Zaidman-Zait, et al., 2016). Approximately $70 \%$ of parents with children with autism have a high level of parenting stress compared to parents of children with other developmental disabilities (Cohrs \& Leslie, 2017; Hayes \& Watson, 2013). Mothers with autistic children feel that their household duties are becoming increasingly heavy (Hoogsteen \& Woogate, 2013).

The problems faced require special solutions in an effort to adapt to the problems and stress faced by parents. Coping is one of the main mechanisms by which parents adapt to the stress of having a child with autism (Benson, 2014). This includes cognitive, emotional, and behavioral processes that allow individuals to adapt to stressors (Zaidman-Zait, et al., 2016).

There are two coping strategies that individuals can use, namely problem-focused coping and emotion-focused coping. Research conducted by Dina et al (2017) shows that single mothers who have children with autism overcome problems with emotion focused coping, most mothers cope with escaping (rejection and wishful thinking), social-emotional support 
(family and environment), self-control (patient), distancing (avoiding problems) and accepting responsibility (acceptance and responsibility).

Based on a preliminary study conducted with several parents of children with special needs in Special School 1 Kendari show that at first they feel sad, ashamed, angry with the situation, and do not expect their child to have a mental disorder. However, after some time, the parents began to accept and try to give their best attention to their children. This can be shown from the attention of parents who send their children to Special School 1 Kendari. From these problems, the researchers took the initiative to examine the analysis of coping behavior of parents who have children with special needs (autism) in Special School 1 Kendari.

\section{Methods}

This type of research is a qualitative research with a case study approach. This research was conducted at the Special School 1 Kendari, Southeast Sulawesi, Indonesia. Participants were selected via purposive sampling. The information in study were 14 people cosisting of parents, families, teachers, principals and health workers.

Method of data used in this research is indepth interviews and observation. Analysis of the data used in this research is content analysis which is a way to find the meaning of written or visual material by way of systematic content allocation to the detailed categories by dividing the data into small pieces and then coding each part and then gathering the coding into similar and calculated groups.

\section{Results and Discussion}

\section{Parental Coping Behavior in Overcoming Feelings}

Every informant have varied coping behaviors, to overcome the feelings that informants have in dealing with children with special needs (autism). The informants made various efforts to overcome this problem. Based on the results of indepth interviews with informants, there are two forms of coping behavior that are used in overcoming the informants feelings, among others: coping which focuses on emotions and coping that focuses on problems.

Types of coping behaviors that focus on emotions include: crying, worshiping, keeping busy, comforting yourself, and being patient. While the type of coping behavior that focuses on the problem the informant does is seeking emotional support, venting emotional anger with anger or hitting children with special needs (autism), admit mistakes and tell the problem at hand to solve the problem. The following are excerpts from interviews with several informants:

"...I always pray that I will be given great patience and strength in dealing with my own child, this is all I can do after doing efforts such as therapy. I can only surrender to God for the efforts I have done ... " (TM, 48 years old)

"...If I am to overcome all of this, I will draw closer to the Almighty, hopefully I will be given strength in facing my child. By getting closer to God, feeling calmer is not like the first time knowing my child's condition where my feelings are mixed ..." (AN, 58 years old )

Besides informants, they get closer to Allah by praying. Informants need self-reinforcement to deal with children with special needs (autism). Informants said that the informants could do self reinforcement by listening to lectures so that they could reduce the stress burden felt by the informants.

“...What I usually do is open ustadz lectures on YouTube to relieve my stress. One of the ustadz's lectures said that life is full of trials, depending on how sincere or not. So I 
have to be sincere and accept my destiny. My child having autism is God's destiny. I have to be strong and get closer to God. Before I complained a lot but by listening to the lecture I started to realize ... " (SD, 48 years old)

However, when the informant is unable to control his emotions, the informant chooses to calm himself down. Based on the results of the interview that by leaving a child with special needs (autism) in a tantrum, it is able to relieve the stress felt by the informant. Adapun kutipan informan adalah sebagai berikut :

"...When my child is unruly and messes up, I can't stand my child, so to relieve the stress I feel, I go out to calm down. When I returned home I felt calm. But if I don't go out, I will be depressed and it will affect my body condition which makes me sick etc ..." (NT, 43 years old)

\section{Parents Coping Behavior in Overcoming the Conditions of Children with Special Needs (Autism)}

Based on the results of indepth interviews that the coping behavior used by the informants in overcoming the condition of children with special needs (autism) is coping behavior that focuses on problems. Several forms of coping behavior carried out by informants in dealing with children with autism include: (a) seeking information about solutions to dealing with children with autism; ; (b) teaching children at home to informants who are busy working; (c) the informant brings the child to therapy services; (d) avoid foods containing gluten and casein; (e) send children with special needs (autism) to school.

The informant revealed that he got information from the family to bring the child to therapy services, after the informant told the problem at hand. The interview excerpt is as follows:

"...I happened to tell my cousin in Kendari, he said that there was a therapy place for children with autism and he knew that place. So I went to Kendari so that my child would be treated with the hope that my child can change and become better ..." (TM, 48 years old)

Information from the main informant is also in line with the statement of the supporting informant (therapist) that the informant must find the right solution for children with special needs (autism) by handling medical rehabilitation doctors, such as occupational therapy. This was stated by the supporting informant in the following expression:

"...Looking for solutions that really improve the condition of children with autism, such as taking them to a medical rehabilitation center, which is then handled by an expert profession so that the handling of autistic children is right on target. Autistic children need a lot of patience, so parents must be ready to deal with these children..." (KY, 35 years old )

In addition, informants should avoid foods and drinks containing gluten and casein for children with special needs (autism).

"...Since I found out that my child is autistic. I started going to google, then I went to therapy at the autism center. I was told that the foods that children with autism should not eat are foods that contain gluten and casein. Children like this eat not like normal children just given it. Alhamdulillah, after I guarded against food that cannot be eaten for autistic children, my child has shown many changes ..." (SM, 39 years old)

The informant brought the child to therapy services. However, after the child is 6 years old, the therapist advises parents to enroll the child in elementary school so that the child can 
socialize with friends his age. The following is an excerpt from the interview with the informant:

"...Almost 2 years I was under the autism center service. However, when my child was 6 years old, the therapist suggested giving him a kindergarten so he could socialize. Finally I gave kindergarten but he didn't want to go to class, he was just at the playground. Later in Special School 1 Kendari he want to enter and sit in class ... " (KM, 42 years old)

Informants coping behavior by sending children with special needs (autism) to school is the last way that informants can do. One of the informants said that in order to send their children to school, the informant had to leave the city and away from the family in the hope that the child could change.

"...I have already done taking children to therapy, so now all I can do is send them to school with the hope that the child can change. I really want to see my children go to school like children in general, until I have to leave my husband and children in the village because in the village there are no schools for children with special needs ..." (AM, 40 years old)

In an effort to overcome the problem, the type of coping behavior that will be used depends on the type of stress or problem at hand (Evans \& Kim, 2013). This study found that there are two coping behaviors carried out by parents who have children with special needs (autism) in overcoming feelings, namely emotional focused coping and problem focused coping.

The informants in this study used coping that focuses on emotions to deal with the stress that the informants felt was caused by internal factors. The types of coping that focus on emotions carried out by the informants include: self-control (crying, patience), positive / positive reappraisa thinking (worship), distancing (keeping yourself busy and entertaining yourself).

Coping behavior that focuses on problems (problem focus coping) in this study, among others: social seeking social support both emotional support and instrumental support, planful problem solving / admitting mistakes), confrontative coping / confrontational (angry, hitting).

Patience and crying (self controling) are coping behaviors that are generally carried out by some informants when dealing with children with special needs (autism). This behavior is an effort that informants can do in controlling the thoughts and emotions they feel so that the informant is able to deal with children with special needs (autism).

Besides being patient and crying, the coping behavior of worship is also done by parents who have children with special needs (autism). The informants believed in religion by worshiping. The coping behavior of worship is considered to be able to help informants in dealing with the perceived pressure so that the informants pray for patience and strength in caring for children with special needs (autism).

Several previous studies have revealed that there is a relationship between religion and parenting stress for mothers who have autistic children (Ayun, 2017). Parents who have high belief in religion can feel positive emotions to get up, be patient, sincere, and have the selfacceptance that their parents have (Rahayu et al., 2019).

In this study, some parents chose to withdraw, avoid and do maladaptive coping in caring for children with special needs (autism). This is done to relieve the pressure felt by parents. Maladaptive coping was also carried out and expressed by participants in Hastings \& Brown (2002); Seymour (2012); Benson (2014) found that coping behavior is carried out by parents 
who have autistic children. Maladaptive behavior is associated with decreased well-being and increased stress and adaptive behavior is associated with positive mental health.

Furthermore, coping behavior that focuses on the problem that is generally carried out by the informants is seeking social support. In line with this research, in the research of Mekki, (2012); Nolcheva \& Trajkovski (2015); Rahman et al., (2018) found that parents seek informative support, ask for opinions and support from closest friends or parents in taking care of children with autism. Support is considered a coping mechanism that is often used by parents with children with autism. Social support is beneficial for parents after getting a child's diagnosis.

In addition to seeking social support, coping behavior focuses on problems carried out by parents, namely confrontational coping, sometimes parents who have children with special needs (autism) have emotions with anger and hitting. This coping behavior is carried out by some parents when children with special needs (autism) make mistakes. Therefore, Based on the description above, it can be explained that the coping behavior carried out by parents in overcoming feelings includes coping which focuses on emotions and coping that focuses on problems. Coping behaviors that focus on emotions carried out by parents in this study include avoidance, self-control and worship. Meanwhile, coping behavior that focuses on the problem is seeking social support, confrontational coping and planning problem solving.

The coping behavior in overcoming the condition of children with special needs (autism) carried out by informants in the study is coping behavior that focuses on problems. The type of coping behavior that focuses on the problem being carried out is planning problem solving (planful problem solving).

Children with special needs (autism) have complex disorders, so parents do several things in overcoming children with special needs (autism) by finding and taking direct action as an effort to cure children and parents' responsibilities so that children can grow and develop normally like children his age.

Some of the coping efforts made by parents in dealing with children with special needs (autism) are finding information about solutions for children with autism, informants bringing children to therapy services, teaching children at home, sending children with special needs (autism), and avoiding foods containing gluten and casein.

The results of the above research are in accordance with the research conducted by Saragih (2018) that parents do various ways by bringing children to health services to see doctors and for therapy. Some parents immediately bring their child for therapy, after knowing the diagnosis of the child with autism, parents also carry out home care such as giving medicine or vitamins to the child that has been prescribed by a doctor.

The results of this study indicate that after the informant did the coping behavior, he brought the child to the therapy setting and sent the child to school. The informant saw that there were changes shown by the child, such as being good at drawing, counting, and playing the piano so that the informant was happy with the effort he had done.

If the coping behavior is done well by parents, it will produce results on the behavior of children with autism. These results are in accordance with previous research which revealed that providing therapy in the hospital can provide solutions to children who have autism and have a level of welfare in mothers with autistic children (Rahmania et al., 2016).

This research is in line with research conducted by Nisa (2017) that parents who bring their children to the Klaten Voluntary Hospital for approximately 1 year are treated and then the 
parents send their children to Special School Sukoharjo. Parents see progress slowly when children go to school, such as being able to speak, read, write, memorize class material and memorize prayer readings and short letters.

Besides giving therapy, the informant also had to do a diet for the child. Children with autism are advised by doctors to avoid foods containing gluten and casein. The results of research conducted by Sukoco et al (2014) show that the diet carried out by parents to children has a good impact on children's behavior to live more regularly and prevent aggression in children.

When children with autism are given foods containing gluten and casein by their parents, they will show screaming, screaming, hitting themselves and others, breaking objects, and hyperactive behavior in children and others (Rahmah et al., 2015). In this study, not all informants could obey to avoid foods containing gluten and casein. Some informants found it difficult to avoid foods containing gluten and casein because of the unfavorable environment, where foods containing gluten and casein were easily available to children with autism.

\section{Conclusion}

Coping strategies used by parents to overcome feelings are emotional focused coping and problem focused coping. Forms of emotional focused coping include worship, crying, being patient, keeping yourself busy and entertaining yourself. Meanwhile, the forms of problem focused coping include seeking support, getting angry, hitting and admitting mistakes. Coping strategies are used to overcome the condition of children with special needs (autism), parents use problem focused coping with the form of planful problem solving behavior. Planful problem solving behaviors include following therapy, dietary food, teaching children at home, alternative medicine and taking medication.

\section{References}

Ashburner, J., Ziviani, J., \& Rodger, S. (2008). Sensory processing and classroom emotional, behavioral, and educational outcomes in children with autism spectrum disorder. American journal of occupational therapy, 62(5), 564-573.

Ashburner, J., Ziviani, J., \& Rodger, S. (2010). Surviving in the mainstream : Capacity of children with autism spectrum disorders to perform academically and regulate their emotions and behavior at school. Research in Autism Spectrum Disorders, 18-27.

Ayun, Q. (2017). Pola Asuh Orang Tua dan Metode Pengasuhan Dalam Membentuk Kepribadian Anak. ThufuLA: Jurnal Inovasi Pendidikan Guru Raudhatul Athfal, 5(1), 102-122.

Benson, P. R. (2014). Coping and psychological adjustment among mothers of children with ASD: An Aacelerated longitudinal study. Journal of Autism and Developmental Disorders, 1793-1807.

Berkovits, L., Eisenhower, A., \& Blacher, J. (2017). Emotion regulation in young children with autism spectrum disorders. Journal of Autism and Developmental Disorders, 47(1), 68-79.

CDC. (2020). Prevalence of Autism Spectrum Disorder Among Children Aged 8 Years Autism and Developmental Disabilities Monitoring Network, 11 Sites, United States, 2016. Available from: https://www.cdc.gov/mmwr/volumes/69/ss/ss6904a1.htm 
Cohrs, A. C., \& Leslie, D. L. (2017). Depression in parents of children diagnosed with autism spectrum disorder: A claims-based analysis. Journal of Autism and Developmental Disorders, 47(5), 1416-1422.

Daulay, N. (2016). Gambaran ketangguhan ibu dalam mengasuh anak autis. Psikohumaniora: Jurnal Penelitian Psikologi, 1(1), 49-74.

Dina E.F., Hermawan, F., \& Virgin. (2017). Emotion-Focused Coping in Single Mother who has Adolescence with Autism. GUIDENA: Jurnal Ilmu Pendidikan, Psikologi, Bimbingan dan Konseling, 7(2).

Ekaningtyas, N. D. (2019). Parenting education guna meningkatkan parenting self-efficacy pada orang tua dari anak dengan gangguan autisme. Pendidkan Anak Usia Dini, 4(1), 30-39.

Hastings, R. P., \& Brown, T. (2002). Behavior problems of children with autism, parental self-efficacy, and mental health. American journal on mental retardation, 107(3), 222-232.

Hayes, S. A., \& Watson, S. L. (2013). The impact of parenting stress: A meta-analysis of studies comparing the experience of parenting stress in parents of children with and without autism spectrum disorder. Journal of autism and developmental disorders, 43(3), 629-642.

Hoogsteen, L., \& Woogate, R. L. (2013). The lived experience of parenting a child with autism in a rural area : Making the invisible, visable. Journal of Pediatric Nursing, 33-37.

Judarwanto, W. (2015). Jumlah Penderita Autis di Indonesia. Pediatri.

Mekki, K. (2012). Stress and coping in mothers of children with autism spectrum disorders, Doctoral dissertation, Université d'Ottawa/University of Ottawa.

Nisa, A. C. (2017). Improving the Effectiveness of Learning Using Pictures Cards" Rocky Dust" for Students with Disorder Autism Sensory Integration in SLB-B TPA Jember, East Java, Indonesia. Journal of Education and Practice, 8(9), 196-202.

Nolcheva, M., \& Trajkovski, V. (2015). Exploratory Study: Stress, Coping and Support among Parents of Children with Autism Spectrum Disorders. Journal of special education and rehabilitation.

Rahayu, A. T., Matuzzahroh, N., \& Amalia, S. (2019). Religiusitas dan stres pengasuhan pada ibu dengan anak autis. Jurnal ilmiah psikologi terapan, 07(02), 252-269.

Rahmah, J., Diani, N., \& Rachmawati, K. (2015). Kepatuhan orang tua tentang diet gluten free dan casein free dengan perilaku anak autis. Dunia Keperawatan: Jurnal Keperawatan dan Kesehatan, 3(2), 16-25.

Rahmania, R., Nurwati, N., \& Taftazani, B. M. (2016). Strategi Koping Ibu Dengan Anak Gangguan Spektrum Autisme:(Studi Kasus: Orangtua Murid Taman Kanan-Kanak Mutiara Bunda). Prosiding Penelitian dan Pengabdian kepada Masyarakat, 3(3), 334.

Rahman, Z. A., Awang, J., Ibrahim, M., Kamarzaman, M. H., Yusof, M., Abdul Kadir, F. A., \& Mohamed, S. (2018). Element of silent repetition of prayers and self-reflection or introspection approaches in coping problematic behaviors among 
adolescents. International Journal of Civil Engineering and Technology, 9(7), 261268.

Rieffe, C., De Bruine, M., De Rooij, M., \& Stockmann, L. (2014). Approach and avoidant emotion regulation prevent depressive symptoms in children with an Autism Spectrum Disorder. International Journal of Developmental Neuroscience, 39, 3743.

Safaria. (2005). Autisme, Pemahaman untuk hidup lebih bermakna bagi orang tua, Jogyakarta: Graha Ilmu.

Samson, A. C., Wells, W. M., Phillips, J. M., Hardan, A. Y., \& Gross, J. J. (2015). Emotion regulation in autism spectrum disorder: evidence from parent interviews and children's daily diaries. Journal of Child Psychology and Psychiatry, 56(8), 903-913.

Saragih, J. B. (2018). Limitedness of space in coastal settlement area; how children create their playground. In IOP Conference Series: Earth and Environmental Science. IOP Publishing (p. 012090).

Seymour, W. (2012). Remaking the body: Rehabilitation and change. Routledge.

Soetjiningsih. (2014). Tumbuh Kembang Anak Edisi 2. Jakarta: EGC.

Sukoco, N. E. W., Pambudi, J., \& Herawati, M. H. (2015). Hubungan status gizi anak balita dengan orang tua bekerja. Buletin Penelitian Sistem Kesehatan, 18(4), 387-397.

WHO. (2019). Autism Spectrum Disorders. Available from: https://www.who.int/newsroom/fact-sheets/detail/autism-spectrum-disorders.

Zaidman-Zait, A., Mirenda, P., Duku, E., Vaillancourt, T., Smith, I. M., Szatmari, P., et al. (2016). Impact of personal and social resources on parenting stress in mothers of children with autism spectrum disorder. Autism: The International Journal of Research and Practice. 